\title{
ANTIOXIDANT AND IMMUNE-STIMULATING ACTIVITIES OF HOT-WATER EXTRACT FROM SEAWEED SARGASSUM HEMIPHYLLUM
}

\author{
Pai-An Hwang \\ Seafood Technology Division, Fisheries Research Institute, Council of Agriculture, Keelung, Taiwan, R.O.C, \\ pahwang@mail.tfrin.gov.tw \\ Chwen-Herng Wu \\ Seafood Technology Division, Fisheries Research Institute, Council of Agriculture, Keelung, Taiwan, R.O.C \\ Shu-Yun Gau \\ Seafood Technology Division, Fisheries Research Institute, Council of Agriculture, Keelung, Taiwan, R.O.C \\ Shih-Yung Chien \\ Seafood Technology Division, Fisheries Research Institute, Council of Agriculture, Keelung, Taiwan, R.O.C \\ Deng-Fwu Hwang \\ Department of Food Science, National Taiwan Ocean University, Keelung, Taiwan, R.O.C.
}

Follow this and additional works at: https://jmstt.ntou.edu.tw/journal

Part of the Aquaculture and Fisheries Commons

\footnotetext{
Recommended Citation

Hwang, Pai-An; Wu, Chwen-Herng; Gau, Shu-Yun; Chien, Shih-Yung; and Hwang, Deng-Fwu (2010) "ANTIOXIDANT AND IMMUNE-STIMULATING ACTIVITIES OF HOT-WATER EXTRACT FROM SEAWEED SARGASSUM HEMIPHYLLUM,"

Journal of Marine Science and Technology. Vol. 18: Iss. 1, Article 5.

DOI: $10.51400 / 2709-6998.1863$

Available at: https://jmstt.ntou.edu.tw/journal/vol18/iss1/5

This Research Article is brought to you for free and open access by Journal of Marine Science and Technology. It has been accepted for inclusion in Journal of Marine Science and Technology by an authorized editor of Journal of Marine Science and Technology.
} 


\title{
ANTIOXIDANT AND IMMUNE-STIMULATING ACTIVITIES OF HOT-WATER EXTRACT FROM SEAWEED SARGASSUM HEMIPHYLLUM
}

\author{
Pai-An Hwang*, Chwen-Herng Wu*, Shu-Yun Gau*, \\ Shih-Yung Chien*, and Deng-Fwu Hwang**
}

Key words: Sargassum hemiphyllum, antioxidant activity, HB4C5 cells, J774.1 cells.

\begin{abstract}
The hot-water extract of seaweed Sargassum hemiphyllum was evaluated antioxidant activity by using four different methods, including DPPH free radicals scavenging activity, $\mathrm{Fe}^{+2}$ chelating activity, superoxide anion radical scavenging activity and reducing power, and the immune-stimulating activity by using HB4C 5 cells and J774.1 cells. It was found that the antioxidant activity was increasing in correlating with the concentration below $3.5 \mathrm{mg} / \mathrm{ml}$. The HB4C5 cells showed the maximum relative activities of cell proliferation (174\%) and $\mathrm{IgM}$ secretion $(132 \%)$ at $120 \mu \mathrm{g} / \mathrm{ml}$ of hot-water extract. Overheating slightly reduced the immune-stimulating activity of hot-water extract. At $80 \mu \mathrm{g} / \mathrm{ml}, \mathrm{J} 774.1$ cells showed the maximum relative activities of cell proliferation $(141 \%)$ and phagocytosis (147\%). Hence, the hot-water extract of seaweed $S$. hemiphyllum plays the important role on antioxidant and immune-stimulating activities.
\end{abstract}

\section{INTRODUCTION}

The brown seaweed, Sargassum sp. (Phaeophyceae), is a common plant which distributes around the coast of Taiwan. Rowboats will get entangled in a widespread and closely layered weed that lies around the coast from March through April. In Taiwan, Sargassum sp. is used as a traditional Chinese medicine for cervical lymphadenitis, edema, allay, urinary diseases, etc [32], but it is not consumed. It has been reported to be the potential source of valuable glycolipids [11], phenolic substances [4] and carbohydrates [3]. Their inhibiting

Paper submitted 03/05/08; revised 08/12/08; accepted 01/21/09. Author for correspondence: Pai-An Hwang (e-mail: pahwang@mail.tfrin.gov.tw).

*Seafood Technology Division, Fisheries Research Institute, Council of Agriculture, Keelung, Taiwan, R.O.C.

**Department of Food Science, National Taiwan Ocean University, Keelung, Taiwan, R.O.C. effects on the atopic allergic reaction [18] and protein bioavailability [30] have been reported, and the seaweed possesses heavy metal accumulation [25]. However, their effects on antioxidant and immune-stimulating activities are not available so far.

Antioxidants inhibit or prevent oxidation of a substrate, and evolve to protect biological systems against damage induced by ROS (reactive oxygen species). Among the sources of natural antioxidants, marine seaweeds are now being considered to be a rich source of antioxidants.

The HB4C5 cells are the human-human hybridomas producing monoclonal antibody against human lung cancer, and J774.1 cells are the murine macrophage-like cell line, both of them have been used in screening of immune-stimulating activity for natural products $[17,23]$. Following this way, the immune-stimulating activity of hot-water extract of seaweed S. hemiphyllum was undertaken.

In this study, we investigated the antioxidant activities of hot-water extract from $S$. hemiphyllum by four different detection methods and the immune-stimulating activity by HB4C5 cells and J774.1 cells. These data should be useful with regard to supporting this seaweed as a Chinese medicine herb.

\section{MATERIALS AND METHODS}

\section{Sample}

Fresh Sargassum hemiphyllum was collected from the coast of Penghu County, Taiwan during a period from January to March, 2006. Seaweed was washed and dried in a current air with dryer (RISEN Co., LTD, RHD-602D) at $40^{\circ} \mathrm{C}$ for $90 \mathrm{~min}$. The dried sample was ground to flour with a mini blender (D3V-10, YOUQI, Taiwan) and then further dried with a dryer (RISEN Co., LTD, RHD-602D) at $50^{\circ} \mathrm{C}$ for $10 \mathrm{~min}$. The dried seaweed $(100 \mathrm{~g})$ was treated with 51 of distilled water and boiled $\left(100^{\circ} \mathrm{C}\right)$ for $30 \mathrm{~min}$. The extracts were centrifuged at 4,500 rpm for $20 \mathrm{~min}$, and the supernatant was lyophilized under reduced pressure under as following condition: The temperature was about $-20^{\circ} \mathrm{C}$, the pressure was about $2 \mathrm{mmHg}$ (EYELA, FDU-1200), and the hot-water extract was then kept 
at $-20^{\circ} \mathrm{C}$ for the following tests. The test solution was prepared of the freeze-dried hot-water extract dissolving in distilled water.

\section{Reagents}

1,1-Diphenyl-2-picrylhydrazyl (DPPH), 3-(2-pyridyl)-5,6-bis (4-phenyl-sulfonic acid-1, 2, 4-triazine (Ferrozine, trichloracetic acid (TCA), potassium hexacyanoferrate $\left[\mathrm{K}_{3} \mathrm{Fe}(\mathrm{CN})_{6}\right]$, nitroblue tetrazolium salt (NBT), xanthine oxidase (XOD), ethylenediaminetetraacetic acid disodium salt (EDTA), and L-ascorbic acid were purchased from Sigma Chemical Co. (St. Louis, USA). Other reagents were analytic grade.

\section{Chemical Composition Analysis}

The test solution was analyzed for total sugar, protein, uronic acid, sulfate and total phenolic compounds. Total sugar was determined by the phenol- $\mathrm{H}_{2} \mathrm{SO}_{4}$ method using glucose as the standard [8]. Protein was determined by Lowry method [15]. Uronic acid was determined by the procedure of Hoogen et al. [10]. Sulfate was determined by the method of Dodgson and Prince [7]. And total phenolic compounds was determined by the Folin-Ciocalteu method using gallic acid as the standard [29]. The approximate chemical compositions of freeze-dried hot-water extract were determined by AOAC method [1], including moisture, crude protein, crude fat, ash and total carbohydrate.

\section{DPPH Free Radicals Scavenging Activity Assay}

The scavenging activity for DPPH free radicals was measured according to the method of Shimada et al. [26]. DPPH solution was prepared at the concentration of $0.1 \mathrm{mM}$ in ethanol. During the assay, the $1 \mathrm{ml}$ of test solution (concentration of $0.5-3.5 \mathrm{mg} / \mathrm{ml}$ ) was mixed with $1 \mathrm{ml} \mathrm{DPPH}$ solution. The mixture was incubated in dark place for $30 \mathrm{~min}$ at $25^{\circ} \mathrm{C}$. After standing for $30 \mathrm{~min}$, absorbance was recorded at $517 \mathrm{~nm}$ by UV Beckman spectrophotometer (Beckman Coulter). The percentage of DPPH free radicals scavenging activity was calculated by following equation: Scavenging activity = $\left[1-\left(\mathrm{A}_{1}-\mathrm{A}_{2}\right) / \mathrm{A}_{0}\right] \times 100 \% . \mathrm{A}_{0}, \mathrm{~A}_{1}$ and $\mathrm{A}_{2}$ are the absorbance of the control (without test solution), the presence of the test solution, and without DPPH, respectively.

\section{5. $\mathrm{Fe}^{+2}$ Chelating Activity Assay}

The $\mathrm{Fe}^{+2}$ chelating activity of the hot-water extract was determined by the method of Dinis et al. [6]. One millileter of the test solution (concentration of $0.5-3.5 \mathrm{mg} / \mathrm{ml}$ ) was mixed with $3.8 \mathrm{ml}$ of distilled water and $0.1 \mathrm{ml}$ of $2 \mathrm{mM} \mathrm{FeCl}_{2}$. After $30 \mathrm{sec}, 0.2 \mathrm{ml}$ of $5 \mathrm{mM}$ ferrozine was added and reacted for 10 min at room temperature. After that, the absorbance of the $\mathrm{Fe}^{+2}$-ferrozine complex was measured at $562 \mathrm{~nm}$. The chelating activity of the hot-water extract was calculated as following equation: Chelating activity $=\left(\mathrm{A}_{0}-\mathrm{A}_{1}\right) / \mathrm{A}_{0} \times 100 \% . \mathrm{A}_{0}$ and $\mathrm{A}_{1}$ are the absorbance of the control (without test solution) and the presence of the test solution, respectively.

\section{Superoxide Anion Radical Scavenging Activity Assay}

The superoxide anion radical scavenging activity of the test solution was determined by the method of Nagai et al. [19]. The volume of $0.48 \mathrm{ml}$ of $0.05 \mathrm{M}$ sodium carbonate buffer $(\mathrm{pH}$ 10.5), $0.02 \mathrm{ml}$ of $3 \mathrm{mM}$ xanthine, $0.02 \mathrm{ml}$ of $3 \mathrm{mM}$ EDTA, $0.02 \mathrm{ml}$ of $0.15 \%$ bovine serum albumin, $0.02 \mathrm{ml}$ of $0.75 \mathrm{mM}$ NBT and $0.02 \mathrm{ml}$ of the test solution (concentration of 0.5-3.5 $\mathrm{mg} / \mathrm{ml}$ ) were mixed together. After pre-incubating at $25^{\circ} \mathrm{C}$ for $10 \mathrm{~min}$, the reaction was started by adding $6 \mathrm{mU}$ XOD and carried out at $25^{\circ} \mathrm{C}$ for $20 \mathrm{~min}$. And the reaction was stopped by adding $0.02 \mathrm{ml}$ of $6 \mathrm{mM} \mathrm{CuCl}_{2}$ after $20 \mathrm{~min}$. The absorbance at $560 \mathrm{~nm}$ was measured, and the scavenging activity of the hot-water extract was calculated as following equation: Scavenging activity $=\left(1-\mathrm{A}_{1} / \mathrm{A}_{0}\right) \times 100 \% . \quad \mathrm{A}_{0}$ and $\mathrm{A}_{1}$ are the absorbance of the control (without test solution) and the presence of the test solution, respectively.

\section{Reducing Power Assay}

The $\mathrm{Fe}^{+3}$ reducing power of the hot-water extract was determined by the method of Oyaizu [20]. One milliliter of the test solution (concentration of $0.1-1.0 \mathrm{mg} / \mathrm{ml}$ ) was mixed with $1 \mathrm{ml}$ phosphate buffer $(0.2 \mathrm{M}, \mathrm{pH} 6.6)$ and $1 \mathrm{ml}$ of $1 \%$ potassium hexacyanoferrate $\left[\mathrm{K}_{3} \mathrm{Fe}(\mathrm{CN})_{6}\right]$, followed by incubating at $50^{\circ} \mathrm{C}$ in a water bath for $20 \mathrm{~min}$. The reaction was stopped by adding $1 \mathrm{ml}$ of $10 \%$ TCA solution and then centrifuged at $5,500 \mathrm{rpm}$ for $10 \mathrm{~min}$. The supernatant $(1.5 \mathrm{ml})$ was mixed with $1.5 \mathrm{ml}$ of distilled water and $0.1 \mathrm{ml}$ of $0.1 \%$ ferric chloride solution for $10 \mathrm{~min}$. The absorbance at $700 \mathrm{~nm}$ was measured, and higher absorbance indicated greater reducing power.

\section{Proliferation and IgM Secretion Assay in HB4C5 Cells}

HB4C5 cell line was provided from Dr. Zwe-Ling Kong (National Taiwan Ocean University) and cultured in a serumfree eRDF-ITES medium. Cells at log phase were collected by centrifugation at 1,500 rpm for $5 \mathrm{~min}$ and washed with phosphate buffer solution (PBS). One milliliter of the test solution (concentration of $0-180 \mu \mathrm{g} / \mathrm{ml}$ ) was added and cells were cultured for $24 \mathrm{hr}$ at $37^{\circ} \mathrm{C}$ in a humidified $5 \% \mathrm{CO}_{2}$. Cells were treated with water-soluble tetrazolium (WST, 4-[3(4-iodophenyl)-2-(4-nitrophenyl)-2H-5-tetrazolio]-1,3-benzene disulfonate)-1 reageant and OD was read at $570 \mathrm{~nm}$ in a microplate reader [23]. IgM in the culture supernatants was determined by enzyme-linked immunoassay (ELISA) [28], and the absorbance was measured in an ELISA reader (Molecular Devices, Wako, Tokyo) at $410 \mathrm{~nm}$.

In order to consider the manufacturing process, the test solution was further treated with two conditions, $100^{\circ} \mathrm{C}$ for 1 $\mathrm{hr}$ and $121^{\circ} \mathrm{C}$ for $30 \mathrm{~min}$, and then for proliferation and $\mathrm{IgM}$ secretion studies. The relative activity $\%=\left(\mathrm{A}_{1} / \mathrm{A}_{0}\right) \times 100 \%$, $\mathrm{A}_{0}$ and $\mathrm{A}_{1}$ are the absorbance of the control (without test solution) and the presence of the test solution, respectively.

\section{Proliferation and Phagocytosis Assay in J774.1 Cells}

J774. 1 cells, murine macrophage-like cell line, were also 
obtained from Dr. Zwe-Ling Kong and cultured in RPMI 1640 medium supplemented with $10 \%$ heat-inactivated fetal calf serum (FCS), penicillin $\mathrm{G}(100 \mathrm{U} / \mathrm{ml})$, and streptomycin (100 $\mu \mathrm{g} / \mathrm{ml}$ ). One milliliter of the test solution (concentration of $0-120 \mu \mathrm{g} / \mathrm{ml}$ ) was added and cells were cultured for $24 \mathrm{hr}$ at $37^{\circ} \mathrm{C}$ in an atmosphere of $5 \% \mathrm{CO}_{2}$. Cells were also treated with WST-1 reagent and OD was read at $570 \mathrm{~nm}$ in a microplate reader. The phagocytosis assay was determined by Vybrant Phagocytosis Assay Kit (V-6694) (Molecular Probes, Inc., USA), and the fluorescent intensity was read at $480 \mathrm{~nm}$ excitation, $520 \mathrm{~nm}$ emission.

\section{Statistical Analysis}

The data presented are mean \pm S.D. of three to five determinations, and differences were considered to be statistically significant if $\mathrm{P}<0.05$. L-Ascorbic acid was used as a positive control. The value of median inhibit concentration (IC50) for hot-water extract was recognized for inhibiting free radicals concentration by $50 \%$ or absorbance up to 0.5 , and graphically estimated using a liner regression algorithm.

\section{RESULT}

\section{Chemical Composition of Hot-Water Extract of S. hemiphyllum}

The color of freeze-dried hot-water extract from S. hemiphyllum was brown and the approximate chemical compositions were moisture $10.1 \%$, crude protein $38.5 \%$, crude fat $8.4 \%$, ash $12.2 \%$ and total carbohydrate $30.8 \%$. In test solution, the concentrations of total sugar, protein, uronic acid, sulfate, and phenolic compounds were $0.821,0.545,0.053$, 0.140 , and $0.240 \mathrm{mg} / \mathrm{ml}$, respectively.

\section{Antioxidant Activities}

The scavenging activity of hot-water extract from S. hemiphyllum was increasing with increase of concentration and showed a linear relationship $(Y=25.78 X+9.25, r=0.960)$ by determining with DPPH free radicals scavenging activity assay, and the value of IC50 was $1.58 \mathrm{mg} / \mathrm{ml}$. Iron is a transition metal and can accelerate or stimulate lipid peroxidation, while the oxidation of $\mathrm{Fe}^{+2}$ was inhibited by adding the hotwater extract from $S$. hemiphyllum, indicating the chelating activity was a good linear dose-depending relationship ( $\mathrm{Y}=$ $22.71 \mathrm{X}+3.00, \mathrm{r}=0.975)$, and the value of IC50 was 2.07 $\mathrm{mg} / \mathrm{ml}$. Superoxide anion scavenging activity of hot-water extract from $S$. hemiphyllum was measured using the xanthine-xanthine oxidase system, showing the scavenging activity was also a linear dose-depending relationship ( $\mathrm{Y}=$ $18.89 \mathrm{X}+4.50, \mathrm{r}=0.945)$, and the IC50 was $2.41 \mathrm{mg} / \mathrm{ml}$ (Fig. 1). In Fig. 2, the hot-water extract from $S$. hemiphyllum exhibited the $\mathrm{Fe}^{+3}$ reducing power, resulting in a good linear dose-depending relationship $(\mathrm{Y}=1.20 \mathrm{X}+0.01, \mathrm{r}=0.986)$, and the value of IC50 was $0.41 \mathrm{mg} / \mathrm{ml}$. Judging from these results, the hot-water extract of seaweed $S$. hemiphyllum possessed the good antioxidant activities.

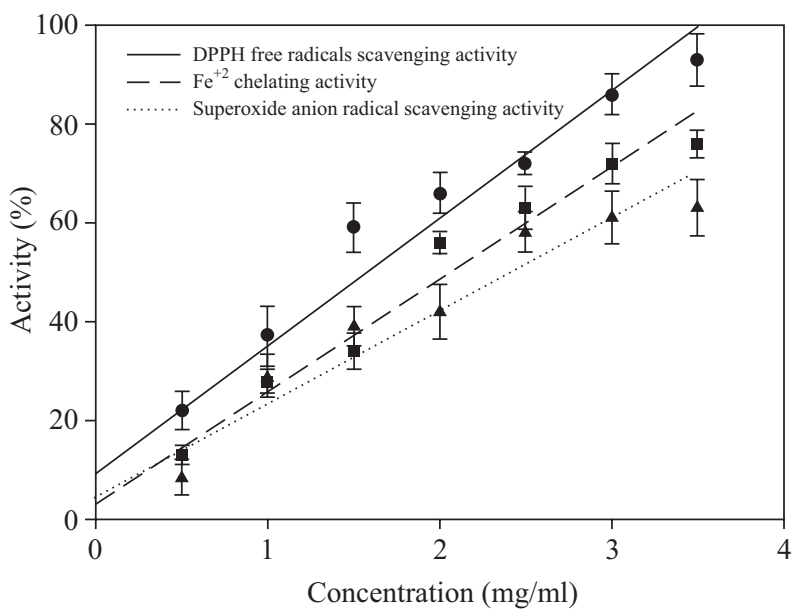

Fig. 1. The dose-related antioxidant activities of the hot-water extract of Sargassum hemiphyllum as determined by the DPPH free radicals scavenging, $\mathrm{Fe}^{+2}$ chelating and superoxide anion radical scavenging tests $(n=5)$.

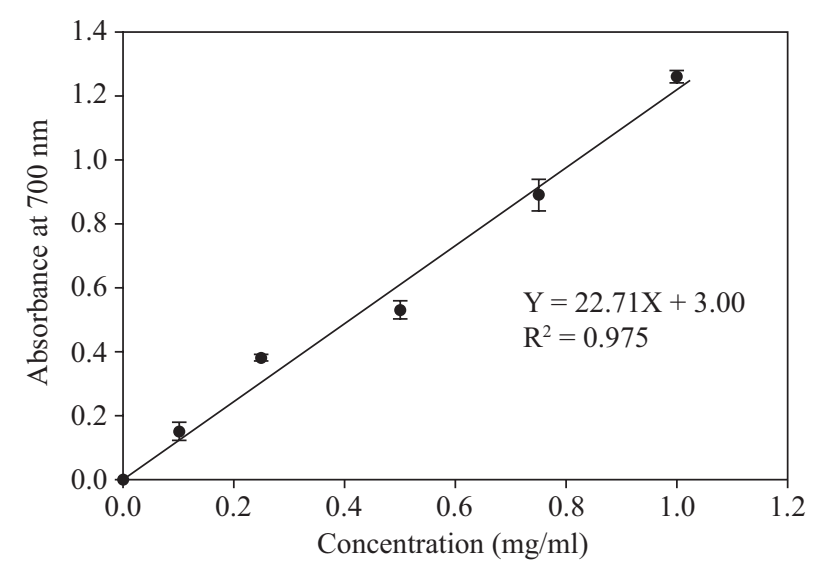

Fig. 2. The dose-related reducing power activity of the hot-water extract of Sargassum hemiphyllum as determined by the reduction of $\mathrm{Fe}^{+3}$ $(\mathbf{n}=\mathbf{5})$.

\section{Proliferation and IgM Secretion in HB4C5 Cells}

The hot-water extract of $S$. hemiphyllum showed the positive relative activity of cell proliferation of $118 \%$ at $30 \mu \mathrm{g} / \mathrm{ml}$ and a maximum relative activity of $174 \%$ at $120 \mu \mathrm{g} / \mathrm{ml}$, resulting in the dose-depending relationship between 0 to 120 $\mu \mathrm{g} / \mathrm{ml}$ (Fig. 3). As indicated in Fig. 4, HB4C5 cells also secreted a linear positive relative activity of $\operatorname{IgM}$ secretion between 0 to $120 \mu \mathrm{g} / \mathrm{ml}$ and showing a maximum of $132 \%$ at 120 $\mu \mathrm{g} / \mathrm{ml}$. The increased amount of IgM in the medium could be regarded as the result of enhancement of specific IgM productivity of each hybridoma cell. This result indicated that the hot-water extract of $S$. hemiphyllum slightly pays a role on immune-stimulating activities. When the $120 \mu \mathrm{g} / \mathrm{ml}$ of hot-water extract from $S$. hemiphyllum was treated with $100^{\circ} \mathrm{C}$ for $1 \mathrm{hr}$ and $121^{\circ} \mathrm{C}$ for $30 \mathrm{~min}$, the relative activity of cell proliferation was slightly decreased and down from $174 \%$ to 


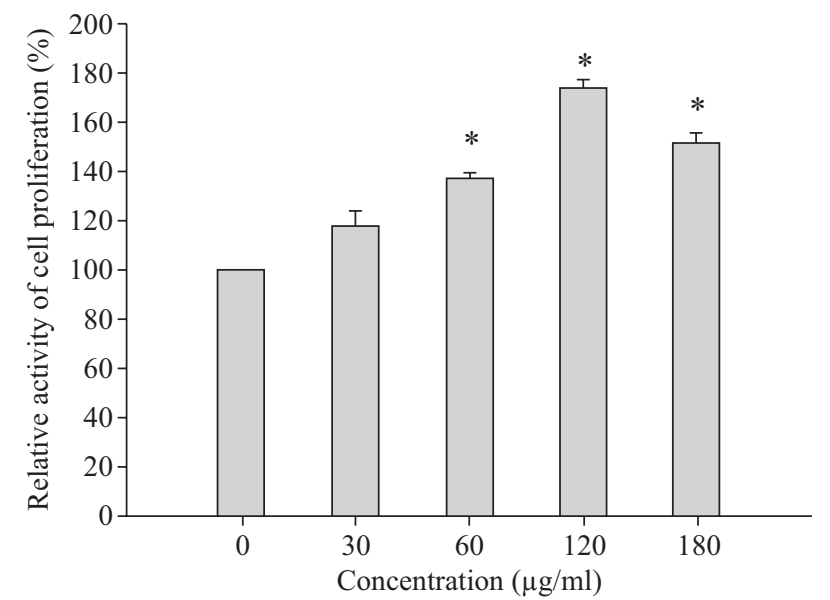

Fig. 3. The dose-related stimulating effect of the hot-water extract of Sargassum hemiphyllum for HB4C5 cells proliferation. The “**", means significant difference $(p<0.05)$ when compared to the control group.

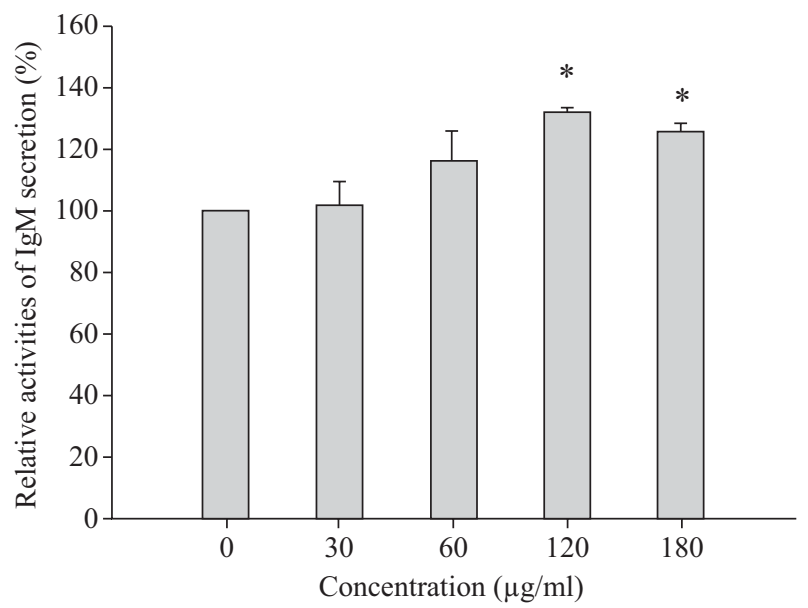

Fig. 4. The dose-related stimulating effect of the hot-water extract of Sargassum hemiphyllum for IgM secretion of HB4C5 cells.

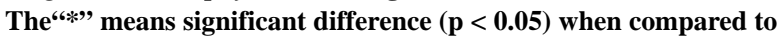
the control group.

$162 \%$ and $168 \%$, respectively. Similarly, the relative activity of $\operatorname{IgM}$ secretion was also down from $132 \%$ to $129 \%$ and $121 \%$, respectively. But there has no significance between 3 groups ( $p>0.05)$ (Fig. 5). It meant that the relative activity of cell proliferation and $\operatorname{IgM}$ secretion of the hot-water extract was comparatively stable when the severe heating occurs.

\section{Proliferation and Phagocytosis Assay in J774.1 Cells}

At $80 \mu \mathrm{g} / \mathrm{ml}$, the hot-water extract of S. hemiphyllum showed significantly the highest proliferation activity of $141 \%$ and phagocytosis activity of $148 \%$ for J774.1 cells (Figs. 6 and 7), while it was also the dosage of maximum relative activity. At 20 and $40 \mu \mathrm{g} / \mathrm{ml}$, the cell proliferation and phagocytosis activity were very close to control, and two activities showed

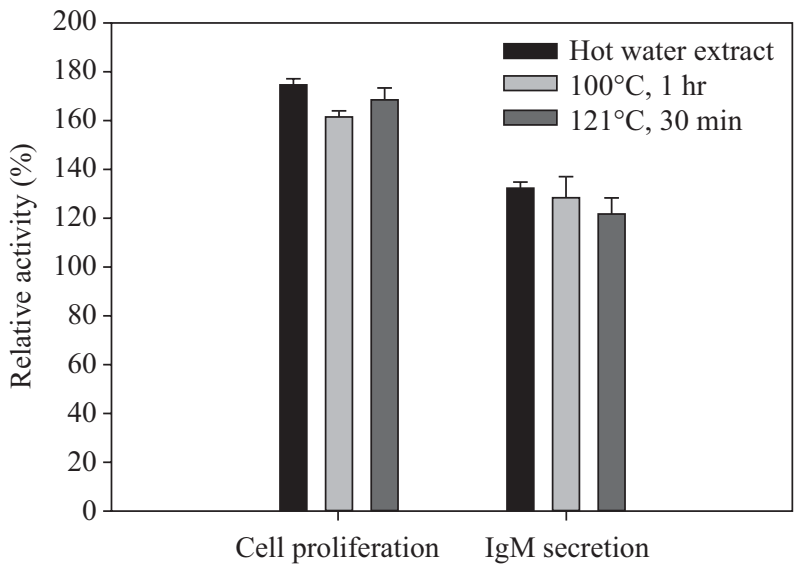

Fig. 5. The heat stability of the hot-water extract of Sargassum hemiphyllum as determined by the relative activities of proliferation and IgM secretion of $\mathrm{HB} 4 \mathrm{C} 5$ cells. Test solutions including the hot-water extract of $S$. hemiphyllum (control) and which by treating $100^{\circ} \mathrm{C}$ for $1 \mathrm{hr}$ and $121^{\circ} \mathrm{C}$ for $30 \mathrm{~min}$. No significant difference $(p>0.05)$ was noticed among these test solutions.

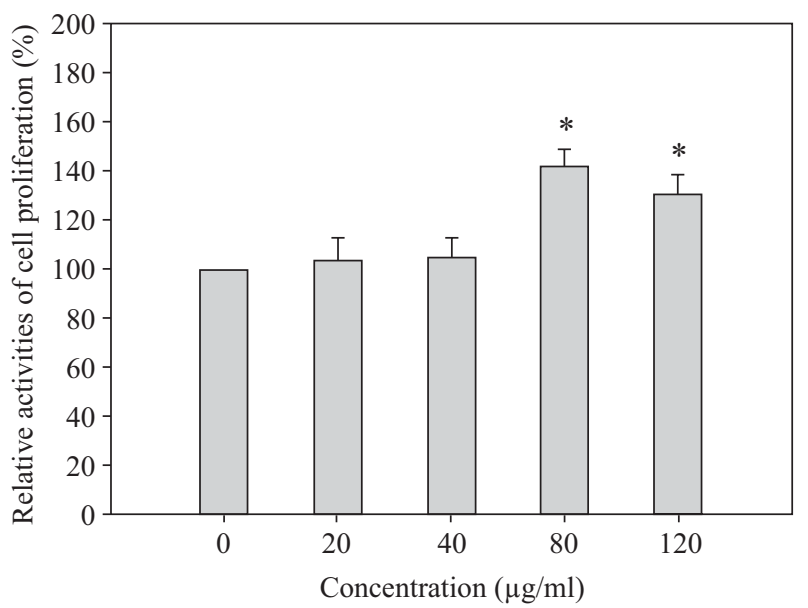

Fig. 6. The dose-related stimulating effect of the hot-water extract of Sargassum hemiphyllum for $\mathbf{J 7 7 4 . 1}$ cells proliferation. The“6*", means significant difference $(p<0.05)$ when compared to the control group.

slightly decreasing at $120 \mu \mathrm{g} / \mathrm{ml}$. There was no linear positive relative between cell proliferation/phagocytosis activity and the concentration of hot-water extract.

\section{DISCUSSION}

The seaweed Sargassum sp. traditionally plays a major role in the management of human ill or as an active role in the health care in many Asia countries [32]. The natural source could help to solve the toxicity issues of synthetic antioxidant compounds. In the present study, we focused on natural hot-water soluble antioxidants and immune-stimulating substances from $S$. hemiphyllum. Judging from four methods to determine the antioxidant activities of hot-water extract from 


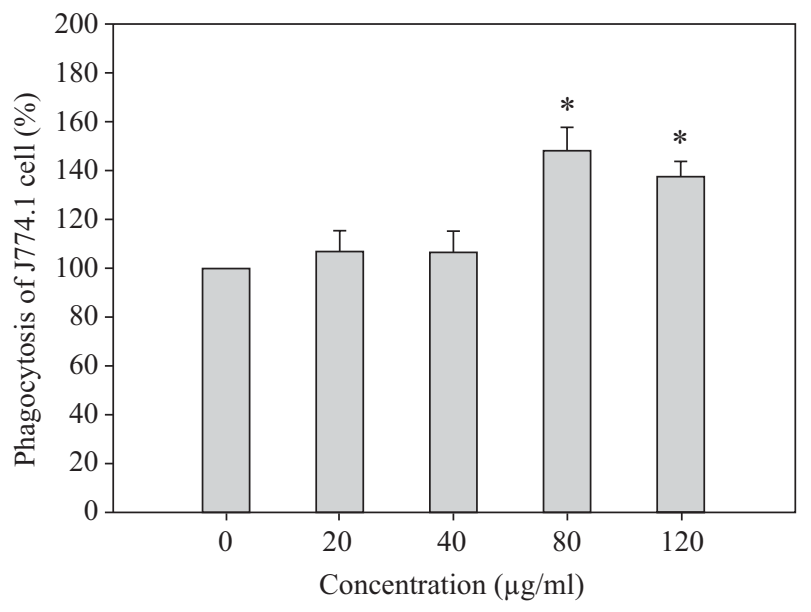

Fig. 7. The dose-related stimulating effect of the hot-water extract of Sargassum hemiphyllum for phagocytosis assay of J774.1 cells. The “**" means significant difference $(p<0.05)$ when compared to the control group.

S. hemiphyllum, it showed that low concentration had good efficacy on antioxidant functions, and all antioxidant activities are positive dose-dependent linear relationships.

Among those assays to evaluate the antioxidant activities of natural substances, DPPH is a free radical donor, which is used to evaluate the free radical scavenging effect of natural antioxidants. The water soluble natural antioxidants from another seaweed $S$. thunbergii exhibited the DPPH free radical scavenging activities, and the scavenging activity of the radicals increased with increasing concentrations of the extract [21]. This result is similar to ours. In addition, the antioxidant activities of commercial enzyme extracts from Sargassum sp. exhibited more prominent effects in hydrogen peroxide scavenging, which was approximately $90 \%$ at $2 \mathrm{mg} / \mathrm{ml}$ [9]. The DPPH free radicals scavenging activity of brown seaweed Ecklonia cava water extract is $48.4 \pm 2.8 \%$ at $100 \mu \mathrm{g} / \mathrm{ml}$ [27]. Furthermore, the DPPH free radicals scavenging activity in some brown seaweed methanol extracts exceeded $50 \%$, the most active seaweed species being Hijiki fusiformis (65\%), followed by Undaria pinnatifida $(51.1 \%)$ and S. fulvellum $(36.3 \%)$ [31].

The extract from $S$. siliquastrum not only showed DPPH free radical scavenging activity but also presented the inhibition of red blood cell hemolysis, suppression of lipid peroxidation and scavenging activity of superoxide radicals [14]. Raghavendran et al. [22] reported that the extract of $S$. polycystum contained some antiulcer agents, which may maintain the volume/acidity of gastric juice and improve the gastric mucosa antioxidant defense system. They further pointed out that the alcoholic extract of $S$. polycystum might be due to the presence of some active compounds that were inhibitory against the free radicals generated during lipid peroxidation in acetaminophen induced toxic hepatitis [2]. In this study, the hot-water extract of $S$. hemiphyllum showed good antioxidant acitivities and contained a lot of phenolic compounds. Hence, it is supposed that those antioxidant activities may be due to high level of total phenolic compounds.

Although various food components have been screened by HB4C5 and J774.1 cells, there has no report for Sargassum sp. so far. In this study, the immune-stimulating activities of hot-water extract in S. hemiphyllum have been screened by using HB4C5 and J774.1 cells. The data showed that the hot-water extract of $S$. hemiphyllum not only could stimulate HB4C5 and J774.1 cells but they were also thermally stable. Yeh et al. [33] reported that administration of hot-water extract of $S$. duplicatum through immersion or injection increased the immune ability of shrimp by increasing total haemocyte count (THC), phenoloxidase activity, respiratory burst and resistance against bacteria. In addition, the extract of $S$. fusiforme showed similar result on immune-stimulating activity of the shrimp [12].

However, S. thunbergii and S. kjellmaniaun have been reported possessing antitumor activity, which is related to the enhancement of immune responses [13]. Although some glycosides are reported to be rich in the seaweeds and may be related to promote immune-stimulating activities, the effective compounds of immune-stimulating activities in these seaweeds are needed to further study. The extract of the brown seaweed Ascophyllum nodosum can enhances immune functions, such as phagocytic activity, red and white blood cell glutathione peroixdase and superoxide dismutase activity, and protected against prolonged heat-induced oxidative stress [24]. Fucoidan, a polysaccharide obtained from natural sources such as brown seaweed, macrophages treated with 10-100 $\mathrm{mg} / \mathrm{ml}$ fucoidan increased phagocytosis, lymphocytes and lysosomal enzyme activity [5]. Brown seaweed Undaria pinnatifida extract significantly enhanced the cytolytic activity of Natural killer cells and increased the amount of interferon (IFN)-gamma produced by $\mathrm{T}$ cells up to about 2 fold compared with non-treated mice [16].

In conclusion, the hot-water extract of seaweed S. hemiphyllum showed good antioxidant and slight immune-stimulating activities by using four different in vitro antioxidant activity testing systems and two cell culture assays. Therefore, the hot-water extract of S. hemiphyllum may be of a benefit to patients suffering from a life style related disease, such as cardiovascular diseases and cancer.

\section{REFERENCES}

1. A.O.A.C. Official Methods of Analysis, 16th ed., Association of Official Analytical Chemists, Maryland (1998).

2. Balaji-Raghavendran, H. P., Sathivel, A., and Devaki, T., "Antioxidant effect of Sargassum polycystum (Phaeophyceae) against acetaminophen induced changes in hepatic mitochondrial enzymes during toxic hepatitis," Chemosphere, Vol. 61, pp. 276-281 (2005).

3. Carrillo-Dominguez, S., Casas-Valdez, M., Ramos-Ramos, F., Perez-Gil, F., and Sanchez-Rodriguez, I., "Marine algae of Baja California Sur, Mexico: nutritional value," Arch Latinoam Nutrition, Vol. 52, pp. 400-405 (2002). 
4. Chkhikvishvili, I. D. and Ramazanov, Z. M., "Phenol compounds from brown algae and their antioxidant activity," Prikl Biokhim Mikrobiological, Vol. 36, pp. 336-338 (2000).

5. Choi, E. M., Kim, A. J., Kim, Y. O., and Hwang, J. K., "Immunomodulating activity of arabinogalactan and fucoidan in vitro," Journal of Medicinal Food, Vol. 8, pp. 446-453 (2005)

6. Dinis, T. C. P., Madeira, V. M. C., and Almeidam, L. M., "Action of phenolic derivates (acetoaminophen, salycilate, and 5-aminosalycilate) as inhibitors of membrane lipid peroxidation and peroxyl radicals scavengers," Archives of Biochemistry and Biophysics, Vol. 315, pp. 161-169 (1994).

7. Dodgson, K. S. and Prince, R. G., "A note on the determination of the ester sulfate content of sulfated polysaccharides," Journal of Biochemistry, Vol. 84, pp. 106-110 (1962).

8. Dubois, M., Gilles, K. A., Hamilton, J. K., Rebers, P. A., and Smith, F., "Colorimetric method for determination of sugars and related substances," Analytical Chemistry, Vol. 28, pp. 350-356 (1956).

9. Heo, S. J., Park, E. J., Lee, K. W., and Jeon, Y. J., “Antioxidant activities of enzymatic extracts from brown seaweeds," Bioresource Technology, Vol. 96, pp. 1613-1623 (2005).

10. Hoogen, B. M., Weeren, P. R., Lopes-Cardozo, M., Golde, L. M. G. Barneveld, A., and Lest, C. H. A., "A microtiter plate assay for the determination of uronic acids," Analytical Biochemistry, Vol. 257, pp. 107-111 (1998)

11. Hossain, Z., Kurihara, H., and Takahashi, K., "Biochemical Composition and lipid compositional properties of the brown alga Sargassum horneri," Pakistan Journal of Biological Science, Vol. 6, pp. 1497-1500 (2003).

12. Huang, X., Zhou, H., and Zhang, H., "The effect of Sargassum fusiforme polysaccharide extracts on vibriosis resistance and immune activity of the shrimp Fenneropenaeus chinensis," Fish Shellfish Immunology, Vol. 20, pp. 750-757 (2006).

13. Itoh, H., Noda, H., Amano, H., Zhuaug, C., Mizuno, T., and Ito, H., "Antitumor activity and immunological properties of marine algal polysaccharides, expecially fucoidan, prepared from Sargassum thunbergii of Phaeophyceae," Anticancer Research, Vol. 13, pp. 2045-2052 (1993).

14. Lim, S. N., Cheung, P. C., Ooi, A. E., and Ang, P. O., "Evaluation of antioxidative activity of extracts from a brown seaweed, Sargassum siliquastrum," Journal of Agriculture and Food Chemistry, Vol. 50, pp. 3862-3866 (2002).

15. Lowry, O. H., Rosebrough, N. L., Farr, A. L., and Randall, R. J., "Protein measurement with the folin reagent," Journal of Biological Chemistry, Vol. 193, pp. 265-275 (1951).

16. Maruyama, H., Tamauchi, H., Hashimoto, M., and Nakano, T., "Antitumor activity and immune response of Mekabu fucoidan extracted from Sporophyll of Undaria pinnatifida," In Vivo, Vol. 17, pp. 245-249 (2003).

17. Masuda, Y., Kodama, N., and Nanba, H., "Macrophage J774.1 cell is activated by MZ-Fraction (Klasma-MZ) polysaccharide in Grifola frondosa," Mycoscience, Vol. 47, pp. 360-366 (2006).

18. Na, H. J., Moon, P. D., Ko, S. G., Lee, H. J., Jung, H. A., Hong, S. H., Seo, Y., Oh, J. M., Lee, B. H., Choi, B. W., and Kim, H. M., "Saragassum hemiphyllum inhibits atopic allergic reaction via the regulation of inflammatory mediator," Journal of Pharmacology Science, Vol. 97, pp.
219-226 (2005).

19. Nagai, T., Sakai, M., Inoue, R., Inoue, H., and Suzuki, N., "Antioxidative activities of some commercially honeys, royal jelly, and propolis," Food Chemistry, Vol. 75, pp. 237-240 (2002).

20. Oyaizu, M., "Antioxidative activity of browning products of glucosamine fractionated by organic solvent and thin-layer chromatography," Nippon Shokuhin Kogyo Gakkaishi, Vol. 46, pp. 571-575 (1988).

21. Park, P. J., Heo, S. J., Park, E. J., Kim, S. K., Byun, H. G., Jeon, B. T., and Jeon, Y. J., "Reaction oxygen scavenging effect of enzymatic extracts from Sargassum thunbergii," Journal of Agriculture and Food Chemistry, Vol. 57, pp. 6666-6672 (2005).

22. Raghavendran, H. R., Sathivel, A., and Devaki, T., "Efficacy of brown seaweed hot water extract against $\mathrm{HCl}$-ethanol induced gastric mucosal injury in rats," Archives of Pharmacal Research, Vol. 27, pp. 449-453 (2004).

23. Ramesh, H. P., Yamaki, K., and Tsushida, T., "Effect of fenugreek (Trigonella foenum-graecum L.) galactomannan fractions on phagocytosis in rat macrophages and on proliferation and IgM secretion in HB4C5 cells," Carbohydrate Polymers, Vol. 50, pp. 79-83 (2002).

24. Saker, K. E., Fike, J. H., Veit, H., and Ward, D. L., "Brown seaweed$\left(\right.$ Tasco $\left.^{\mathrm{TM}}\right)$ treated conserved forage enhances antioxidant status and immune function in heat-stressed wether lambs," Journal of Animal Physiology and Animal Nutrition, Vol. 88, pp. 122-130 (2004).

25. Schiewer, S. and Wong, M. H., "Ionic strength effects in biosorption of metals by marine algae," Chemosphere, Vol. 41, pp. 271-282 (2000).

26. Shimada, K., Fujikawa, K., Yahara, K., and Nakamura, T., "Antioxidative properties of xanthan on the autoxidation of soybean oil in cyclodextrin emulsion," Journal of Agriculture and Food Chemistry, Vol. 40, pp. 945-948 (1992).

27. Shin, H. C., Hwang, H. J., Kang, K. J., and Lee, B. H., "An antioxidative and anti-inflammatory agent for potential treatment of osteoarthritis from Ecklonia cava," Archives of Pharmacal Research, Vol. 29, pp. 165-171 (2006).

28. Shinmoto, H., Murakami, H., Dosako, S., Shinohara, K., and Omura, H., "Human-human hybridomas secreting IgM-like immunoglobulin with $\alpha$ and $\mu$ heavy chains," Agricultural and Biological Chemistry, Vol. 50, pp. 2217-2223 (1986).

29. Singleton, V. L. and Rossi, J. A., "Colorimetry of total phenolic with phosphomolybdic-phosphotungstic acid reagents," American Journal of Enology and Viticulture, Vol. 16, pp. 144-158 (1965).

30. Wang, K. H. and Cheung, P. C., "Effect of fiber-rich brown seaweeds on protein bioavailability of casein in growing rats," International Journal of Food Sciences and Nutrition, Vol. 54, pp. 269-279 (2003).

31. Yan, X., Chuda, Y., Suzuki, M., and Nagata, T., "Fucoxanthin as the major antioxidant in Hijikia fusiformis, a common edible seaweed," Bioscience, Biotechnology, and Biochemistry, Vol. 63, pp. 605-607 (1999).

32. Yao, O., One Chinese Medicine Cures One Illness, Linkingbooks, Taipei, Taiwan, pp. 128-129 (2003).

33. Yeh, S. T., Lee, C. S., and Chen, J. C., "Administration of hot water extract of brown seaweed Sargassum duplicatum via immersion and injection enchances the immune resistance of white shrimp Litopenaeus vannamei," Fish \& Shellfish Immunology, Vol. 20, pp. 332-345 (2006). 